\title{
Impact of conservation practices on runoff and soil loss in the sub-humid Ethiopian Highlands: The Debre Mawi watershed
}

\author{
Dessalegn C. Dagnew ${ }^{1}$, Christian D. Guzman ${ }^{2}$, Assefa D. Zegeye ${ }^{2}$, Tigist Y. Tibebu ${ }^{2}$, Menelik Getaneh ${ }^{3}$, \\ Solomon Abate ${ }^{4}$, Fasikaw A. Zemale ${ }^{1}$, Essayas K. Ayana ${ }^{5}$, Seifu A. Tilahun ${ }^{1}$, Tammo S. Steenhuis ${ }^{2 *}$ \\ ${ }^{1}$ School of Civil and Water Resource Engineering, Institute of Technology, Bahir Dar University, Ethiopia, P.O. Box 26, Bahir Dar, \\ Ethiopia. \\ ${ }^{2}$ Department of Biological and Environmental Engineering, Cornell University, Ithaca, NY 14853, USA. \\ ${ }^{3}$ Amhara Agricultural Research Institute (ARARI), P.O. Box 527, Bahir Dar, Ethiopia. \\ ${ }^{4}$ Eastern Nile Technical Regional Office (ENTRO), P.O. Box 27173-1000, Addis Ababa, Ethiopia. \\ ${ }^{5}$ Department of Ecology, Evolution and Environmental Biology, Columbia University, New York, NY, USA and the Nature Conservancy, \\ Arlington, VA, USA. \\ *Corresponding author. E-mail: tss1@cornell.edu
}

\begin{abstract}
In response to the continually increasing sediment concentrations in rivers and lakes, the Ethiopian government is leading an effort where farmers are installing soil and water conservation measures to increase infiltration and reduce erosion. This paper reports on findings from a four year study in the 95 ha Debre Mawi watershed where under the government led conservation works, mainly terraces with infiltration furrows were installed halfway in the period of observation. The results show that runoff volume decreased significantly after installation of the soil and water conservation practices but sediment concentration decreased only marginally. Sediment loads were reduced mainly because of the reduced runoff. Infiltration furrows were effective on the hillsides where rain water could infiltrate, but on the flat bottom lands that become saturated with the progress of the monsoon rain, infiltration was restricted and conservation practices became conduits for carrying excess rainfall. This caused the initiation of gullies in several occasions in the saturated bottomlands. Sediment concentration at the outlet barely decreased due to entrainment of loose soil from unstable banks of gullies in the periodically saturated bottom areas. Since most uphill drainage were already half filled up with sediments after two years, long term benefits of reducing runoff can only be sustained with continuous maintenance of uphill infiltration furrows.
\end{abstract}

Keywords: Runoff; Soil loss; Sediment concentration; Blue Nile Basin; Soil and water conservation.

\section{INTRODUCTION}

Some of the challenges to the economic development of Ethiopia are soil erosion and soil fertility decline, water scarcity, shortage of pasture as all these result in vicious circle of poverty, food insecurity and natural resources degradation trap. In the Blue Nile Basin, human pressure has increased since the 1950 's and has led to deforestation, expansion of agriculture into steep slopes and overgrazing. As a consequence, most of the hill-sides have become degraded in the Ethiopian highlands where over $85 \%$ of the country's population lives and are devoid of their original vegetation, the most degraded areas have become marginal for crop production (Bewket and Sterk, 2002; Dejene, 2003). Soil erosion affects half of the agricultural land and results in an annual soil loss rate of 1.5 to 2 billion tons. This is equivalent to $35-42$ tons $\mathrm{ha}^{-1}$ year $^{-1}$ and a monetary value of $1-2$ billion USD year ${ }^{-1}$, which otherwise could have added about 1.5 million tons of grain every year to the country's crop productivity (Constable and Belshaw, 1986; Hurni, 1978; Hurni, 1983; Hurni, 1997; Hurni and Tato, 1992; Tamene and Vlek, 2008; Tato and Hurni, 1992).

Average crop yield is low due to soil fertility decline associated with the removal of top soil by erosion (Sertsu, 2000). Constable and Belshaw (1986), estimated that $50 \%$ of the Ethiopian highlands were already "significantly eroded" in the mid 1980 s. This has resulted in a $2.2 \%$ annual decline in land productivity and projected a reduction in per-capita income of the highland population by $30 \%$ (Tamene and Vlek, 2008).
To arrest erosion and reduce its effects, soil and water conservation (SWC) practices were implemented in Ethiopia. They consist of both indigenous SWC practices (such as traditional furrows) and imported SWC practices such as soil bunds, stone bunds and Fanyaa Juu terraces (Mitiku et al., 2006). In addition, crop management practices such as intercropping and land management practices (e.g., minimum tillage) were proposed for reducing runoff and soil erosion by water (Laloy and Bielders, 2010; Mitiku et al., 2006). Although these practices reduce soil loss, they are not being employed in Ethiopia due to the problems with weeds and pests (McHugh et al., 2007). Thus using crop management practices to reduce soil erosion presently is cumbersome for farmers, but could be manageable in the future when pesticide use becomes acceptable and economically feasible.

Most of the SWC programs that were implemented in the Blue Nile Basin over the last 40 years were driven by donor money. The case in point is the largest natural resource conservation program called Food For Work (FFW) run by the Food and Agricultural Organization of the United Nations in the early 1970s and 1980s (Tamene and Vlek, 2008). However, there is no agreement on the effectiveness of SWC interventions implemented so far in Ethiopia. Shiferaw and Holden (1998) from an economic and financial perspective reported that SWC interventions have had positive impacts. Bewket and Sterk (2002) and Herweg and Ludi (1999) found that SWC structures in many cases were not effective in reducing erosion over an extended time period. In semi-arid areas, SWC practices were 
generally effective in reducing runoff, erosion and land degradation (Dejene, 2003) and increasing base flow (Nyssen et al., 2010).

In 2012, a governmental led implementation of large scale watershed management program was launched in Ethiopia as part of the ambitious Growth and Transformation Plan, which aims to double agricultural productivity by strengthening natural resource conservation (MOFED, 2010). In the large scale watershed management program implemented, annually over 3000 community watersheds were treated with physical and biological SWC measures. More than 15 million people are involved in conservation works without payment for the conservation works (except in some food insecure areas paid in kind with safety net programs), covering over 40,000 hectares of land with different SWC measures. Every year, more than 50 million seedlings were planted to revive the forest cover of the country (MOA, 2013).

One of the activities in these large scale SWC interventions is the construction of terraces in the community watersheds of the villages. These practices have changed the landscape appearances because in most parts of the country, soil bunds occupying a width of up to three meters are constructed. Since these programs are large scale interventions currently undertaken in a campaign, assessing its effects on the hydrology, erosion and sediment transport processes would be important for improving the practices. Therefore, the objective of this paper is to evaluate the short term effects of the SWC implementation on runoff and sediment transport responses for a small watershed where prior data is available.

We chose for this evaluation the 95 ha Debre Mawi watershed with two years of discharge and sediment data before SWC implementation and two years of data collected after the SWC intervention to answer questions related to the effect of SWC measures on catchment runoff/discharge and the effect of SWC measures on the catchment sediment transport.

\section{THE STUDY WATERSHED}

The Debre Mawi watershed is situated in the upper Blue Nile Basin $\left(37^{\circ} 22^{\prime} \mathrm{E}\right.$ and $\left.11^{\circ} 18^{\prime} \mathrm{N}\right)$, in the sub-humid Ethiopian highlands (Fig.1). It occupies an area of 95 ha. The slope in the watershed ranges from 1 to $30 \%$, whereas altitude varies from $2,195 \mathrm{~m}$ near the outlet to $2,308 \mathrm{~m}$ in the south east. Tebebu (2009) reported that the annual rainfall of the watershed was $1240 \mathrm{~mm}$, with most of the rainfall concentrated between June and September. It is an agricultural watershed where smallholder farmers produce cereals and the dominant crops produced are 'teff'" (a traditional Ethiopian cereal), maize, finger millet, barley and wheat (Abiy, 2009; Tebebu et al., 2010; Tilahun, 2012).

The soil formation of the watershed is dominated by shallow, highly weathered and fractured basalt overlaid by dark-brown clay, light-brown, wet, sticky-clay and then by black clay and organic rich soil sequences. Intrusive lava dykes are seen across the stream perpendicular to the flow direction of the watershed causing saturation upstream and giving rise to several springs during the wet season (Abiy, 2009; Tilahun et al., 2013a; Tilahun et al., 2013b).

The dominant soil types in the watershed are Nitisols, Vertisols and Vertic Nitisols. Nitisols are red, clay-loam soils found in the upper part of the watershed. These are very deep, well-drained, permeable soils and are suited for cereal cultivation. Vertisols are black soils and cover the lower slope positions. These soils form wide-deep cracks during the dry season and swell during the rainy season. Vertic Nitisols are reddish-brown, well drained, permeable soils, located in the mid-slope locations. These soils have high moisture retention capacity and form cracks when dry and are typically well suited for teff production (Abiy, 2009; Tilahun, 2012).

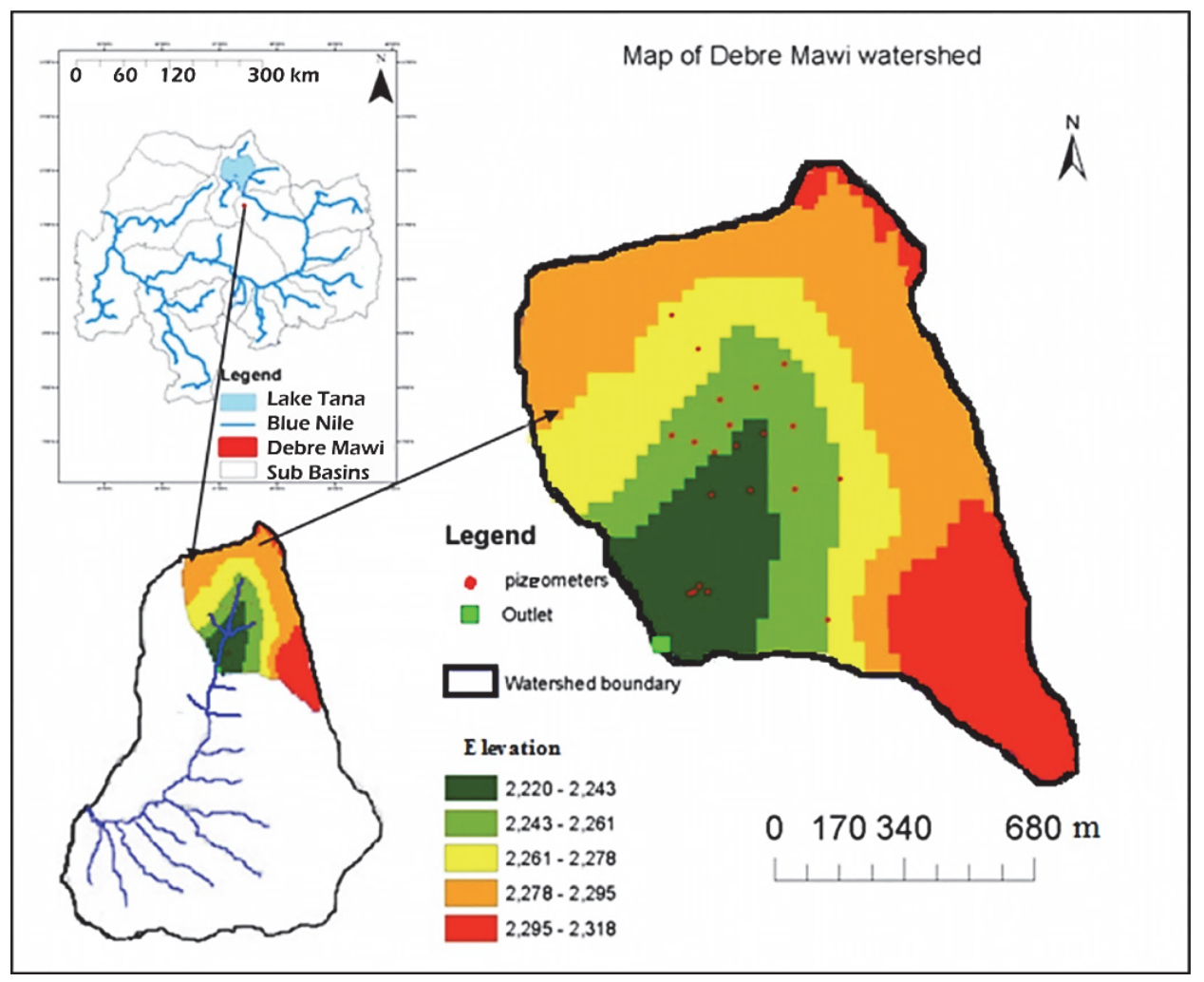

Fig. 1. Map of Blue Nile basin and Debre Mawi watershed. 
The dominant land use system in the watershed is cultivated land $(74 \%)$ followed by grassland $(15 \%)$ and eucalyptus trees and sparse vegetation (11\%). As shown in Fig. 2, one of the land use changes detected in the watershed from 2010 to 2013 was the construction of terraces that occupy nearly four percent of the watershed area as of 2013. Although bunds were planted, our field monitoring showed that these plants did not produce much biomass because they were cut by farmers for cattle feed. So, these features could not be identified on the image. However, since we traced all the bunds in the watershed with GPS, they were included on the map.

Soil and Water Conservation practices in the watershed before 2012 consisted of the traditional furrows installed each year along the contour after ploughing by farmers. In early 2012, various physical and biological SWC measures were installed on most of the agricultural lands as part of the governmental-led SWC campaign. The physical measures include soil bunds with an infiltration ditches that were on the average $50 \mathrm{~cm}$ deep, stone-faced soil bunds and stone bunds. The conservation practices by the government campaign were placed on almost the entire up slope, mid slope and bottom slope positions where cereals were planted (Figs. 2 and 3). To support the physical SWC structures, tree and grass species such as Sesbania (Sesbania grandiflora), vetiver grass (Chrysopogon zizanioides), elephant grass (Pennistum purpureum) and Pigeon Pea ( $\mathrm{Ca}$ janus cajan) were planted on the bunds.

Active gullies (Fig. 4) in the watershed have high erosion losses (Tebebu, 2009; Tebebu et al., 2010; Tilahun, 2012; Zegeye et al., 2010; Zegeye et al., 2014). Despite the fact that most severe erosion was caused by gully formation, in the government led large scale SWC campaign, no gully treatment measures were implemented in the watershed.

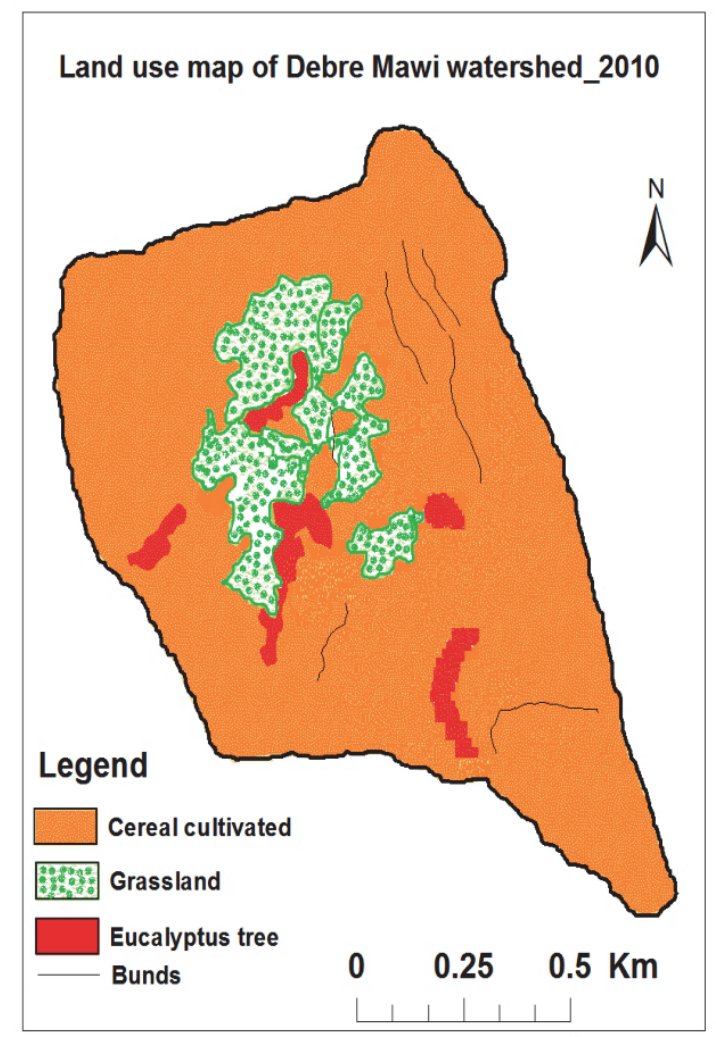

\section{MATERIALS AND METHODS}

Rainfall, stream flow, suspended sediment concentration (SSC), perched ground water table and infiltration data of four years (2010-2013) of the rainy months of the monsoon (June to September) were collected for this study. Outside of these months, the rainfall, runoff and erosion is minimal and inconsequential for evaluating the runoff, erosion and their responses as a result of soil and water conservation implementation.

Rainfall data of 5-minute resolution were obtained from the automatic recording rain gauge installed in the watershed. Automatic recording tipping bucket rain gauge was installed during the rainy season (early June to early October) of the four years. Data from the nearby $(8 \mathrm{~km})$ Adet Agricultural Research Center was used to fill in the missing precipitation data.

Manual measurements of stream flow depth and velocity was conducted by individual observers at the staff gauge and the measurements were done every 10 minutes following the onset of rainfall-runoff events. The surface velocity was determined with a float that was inserted $6 \mathrm{~m}$ upstream from the outlet of the weir. The time required for the float to reach the weir was recorded. The surface velocities were multiplied by two-third to compute the mean discharge. For the weir, a best fit rating curve was developed from all the 10- minute flow depths and mean discharge measurements. A stage discharge curve with a power function was employed to develop the relationship between flow depth and storm discharge. When there was no rain, the recession flow was small and discharge and sediment measurements were not taken.

For sediment concentration analysis, water samples were taken every 10 minutes until the flow declined and the water turned clear (Bosshart, 1995). Between 6 and 20 samples of one

\section{Land use map of Debre Mawi watershed_2013}

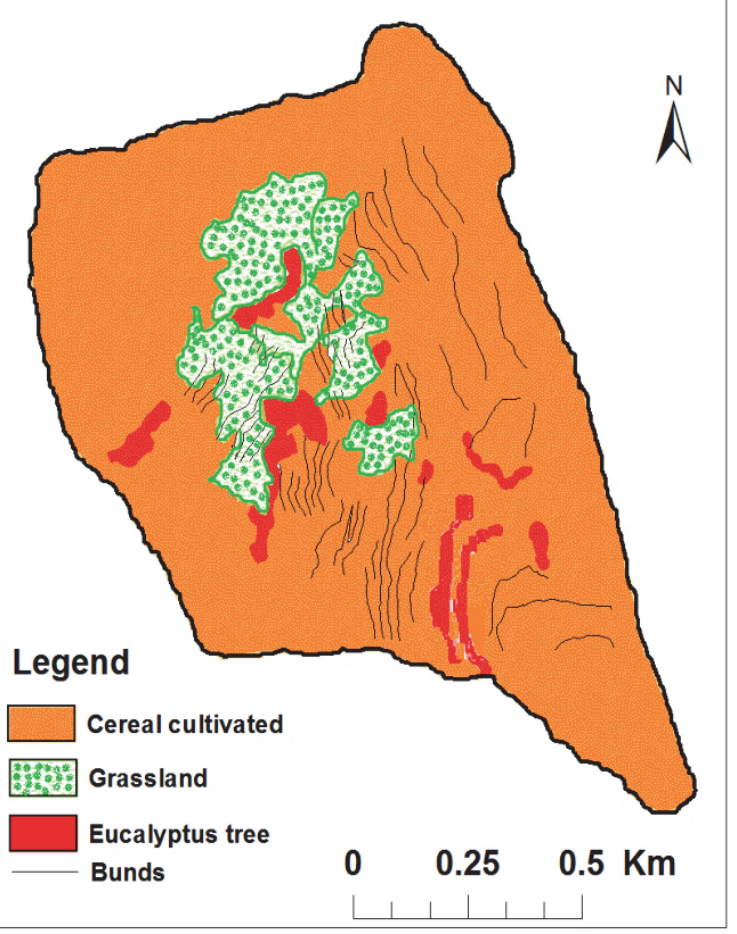

Fig. 2. Land use map of Debre Mawi Watershed before (2010) and after (2013) the soil and water conservation implementation (Source: Google earth digitization, GPS trace and mapping using Arc GIS). 



Fig. 3. Soil and water conservation structures constructed by farmers in Debre Mawi watershed, upper Blue Nile basin.

liter bottles were collected over most of the runoff events. The suspended sediment concentration was determined by filtering through Whatman $320 \mathrm{~mm}$ diameter filter papers and the mass of sediment captured per liter of discharge was determined by weighing the mass of oven dried sediment (Walling, 1974).

Each year, ten to twenty piezometers were installed on the upslope, mid-slope and down slope positions and in places where field observations indicated significant saturation dynamics. The locations were modified throughout the years. The depth to the water table was manually measured two times per day when the groundwater table was in the piezometer range.

Infiltration rates were measured in August 2010 (Tilahun, 2012), July 2012 and August 2013 on more than 10 fields at different slope locations and different land uses using a $25-\mathrm{cm}$ diameter single-ring infiltrometer. Since water did not infiltrate on the saturated bottomlands (Tilahun, 2012), no further measurements of infiltration were done on saturated fields in 2012 and 2013. The constant infiltration rate at the end of the test was taken as the infiltration capacity of the area.

In addition to the above measurements, field observations and photo monitoring was continuously undertaken to under- stand the observed physical process such as erosion, effectiveness and failure of SWC conservation structures through transect walks.

\section{RESULTS \\ Precipitation and infiltration}

Debre Mawi watershed experiences unimodal rainfall which occurs from May to November. Most of the rainfall with great intensities occurs in July and August. Total precipitation for the four months of the monsoon in the studied years was $890 \mathrm{~mm}$, $917 \mathrm{~mm}, 832 \mathrm{~mm}$ and $858 \mathrm{~mm}$, from 2010-2013, respectively. The difference between the driest and wettest year is only 75 $\mathrm{mm}$ (Fig. 5). The maximum hourly rainfall intensity reached 38 $\mathrm{mm} \mathrm{hr}{ }^{-1}$ whereas the maximum daily precipitation was $94 \mathrm{~mm}$ during the four year period.

Measured soil infiltration rates in the watershed varied significantly based on positions in the landscape. Steady state infiltration rates ranged from 6 to $360 \mathrm{~mm} \mathrm{hr}^{-1}$. The median infiltration rates for 2010,2012 and 2013 were $33 \mathrm{~mm} \mathrm{hr}^{-1}$, $24 \mathrm{~mm} \mathrm{hr}^{-1}$ and $31 \mathrm{~mm} \mathrm{hr}^{-1}$, respectively. Infiltration measure- 


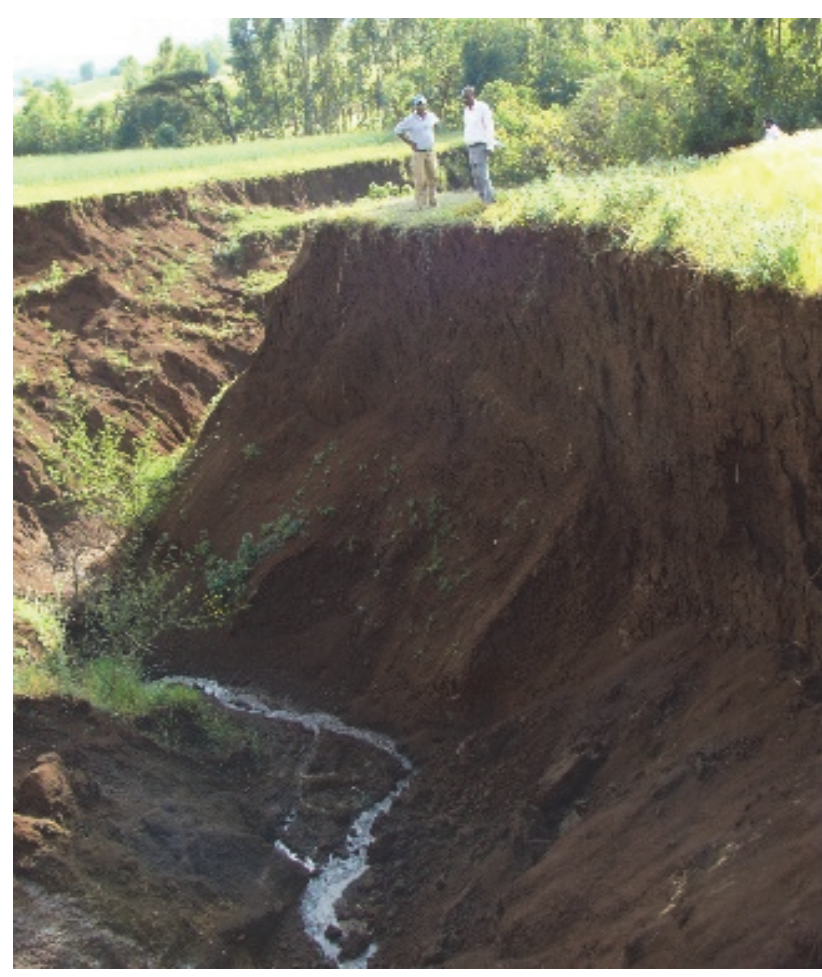

Fig. 4. Photograph of one of the large gullies in Debre Mawi watershed.

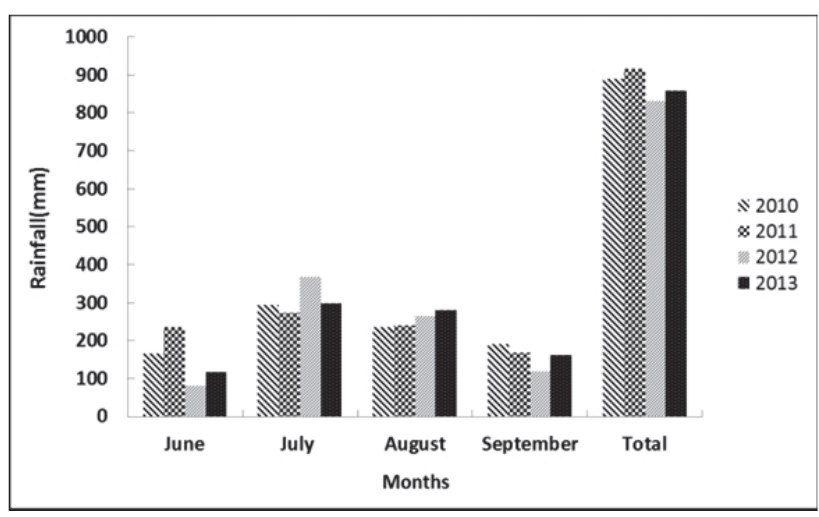

Fig. 5. Monthly precipitation of the monsoon period for Debre Mawi watershed (2010-2013).

ments show that the upslope areas have greater rates of infiltration than the mid slope and down slopes. Comparison of the rainfall intensity and infiltration capacity of soils in Debre Mawi watershed showed that the median infiltration rate is exceeded by the rainfall intensity only $1.5 \%$ in 2010 and $4.4 \%$ in 2011. This indicates that Hortonian flow (infiltration excess overland flow) is not the dominant runoff generation mechanism and thus saturation excess flow (either as interflow or surface runoff) is the main runoff generation mechanism in the Debre Mawi watershed.

\section{Discharge before and after SWC implementation}

The runoff for the monsoon period before the implementation of the SWC practices is shown in Figs. $6 \mathrm{a}$ and $6 \mathrm{~b}$ and after the implementation of SWC practices is presented in Figs. 6c and $6 \mathrm{~d}$ (Note that because the water levels were recorded manually only during the runoff events, the discharge in Fig. $6 \mathrm{a}-\mathrm{d}$ is discontinuous. However, all runoff events were recorded). Larger runoff events, over $20 \mathrm{~mm} \mathrm{day}^{-1}$, occurred on 6/29/2010,
Table 1. Monthly runoff for the Debre Mawi watershed from 2010-2013.

\begin{tabular}{lcccc}
\hline & \multicolumn{4}{c}{ Monthly runoff $\left(\right.$ Thousands of $\left.\mathrm{m}^{3}\right)$} \\
\hline \multirow{3}{*}{ June } & 2010 & 2011 & 2012 & 2013 \\
July & 42.7 & 20.8 & 0.0 & 0.0 \\
August & 134.6 & 104.7 & 15.6 & 27.9 \\
September & 78.4 & 72.6 & 34.7 & 18.6 \\
\hline
\end{tabular}

7/13/2010, 7/29/2010 and 6/12/2011, 7/30/2011. Runoff exceeding $20 \mathrm{~mm}$ day $^{-1}$ occurred only once after the SWC intervention in 2012 and 2013 (compare Figs. 6a and 6b with Figs. $6 \mathrm{c}$ and $6 \mathrm{~d}$ before and after the implementation of SWC programs). Although part of the variability of runoff can be attributed to the rainfall variability, the runoff volumes were distinctly less after the implementation of the SWC practices. The total monsoon runoff volumes before the implementation represented $32 \%$ and $20 \%$ of monsoon rainfalls in 2010 and 2011, respectively. After SWC practices implementation, runoff represented just $10 \%$ and $11 \%$ of monsoon rainfall in 2012 and 2013, respectively. Comparison of runoff volume before and after the SWC implementation for the July and August (in which most of the precipitation falls) indicates that the runoff volume after the intervention has reduced for both July and August (Table 1). Since the rainfall amounts were not greatly different between the years, the reduced surface runoff is related to SWC practices. This is because the rainwater collected in the furrows/ditches of bunds infiltrated in to the soil. The infiltrated water will either evaporate or flow sub-surface down.

\section{Suspended sediment loads and concentrations}

The general temporal trend in sediment loads during the four years of our observations was similar, with the sediment loads in July being the largest (Table 2). Although the pattern is the same, the monthly sediment loads after the implementation of the SWC practices in 2012 and 2013 decreased by a factor of two or more in July and a factor of two in August (Table 2). The annual trend is very distinct where the loads decreased by a factor of four or more. The reduction in sediment loads is mainly caused by the decrease in runoff due to sediment trapped in the ditches of bunds. However, the main reason for the reduction is that most of the sediment was trapped in the newly constructed furrows (Fig. 7) and a smaller degree to a decrease in sediment concentration.

Daily suspended sediment concentrations before and after the SWC implementation are shown in Figs. $8 \mathrm{a}$ and $8 \mathrm{~b}$ and after implementation in Figs 8c and 8d. Flow averaged suspended sediment concentrations reduced from $22 \mathrm{~g} \mathrm{~L}^{-1}$ before SWC implementation to $14 \mathrm{~g} \mathrm{~L}^{-1}$, in the first year after the implementation of SWC measures (in 2012). The lower rainfall in 2012 could have partly contributed to the reduction in sediment concentration in that year. The concentration increased back to almost the previous level $\left(20 \mathrm{~g} \mathrm{~L}^{-1}\right)$ in 2013 (Table 3). The temporal variability of sediment concentration shows that sediment concentrations are greater in the early phase of the monsoon (Fig. 8) because during the early phase, rills form in the recently-plowed soils. They expand when the rainfall amounts of greatest intensities occur in July and gradually decline with the progress of the season (Tebebu, 2009; Tilahun et al., 2013a; Tilahun et al., 2013b; Zegeye et al., 2010). 

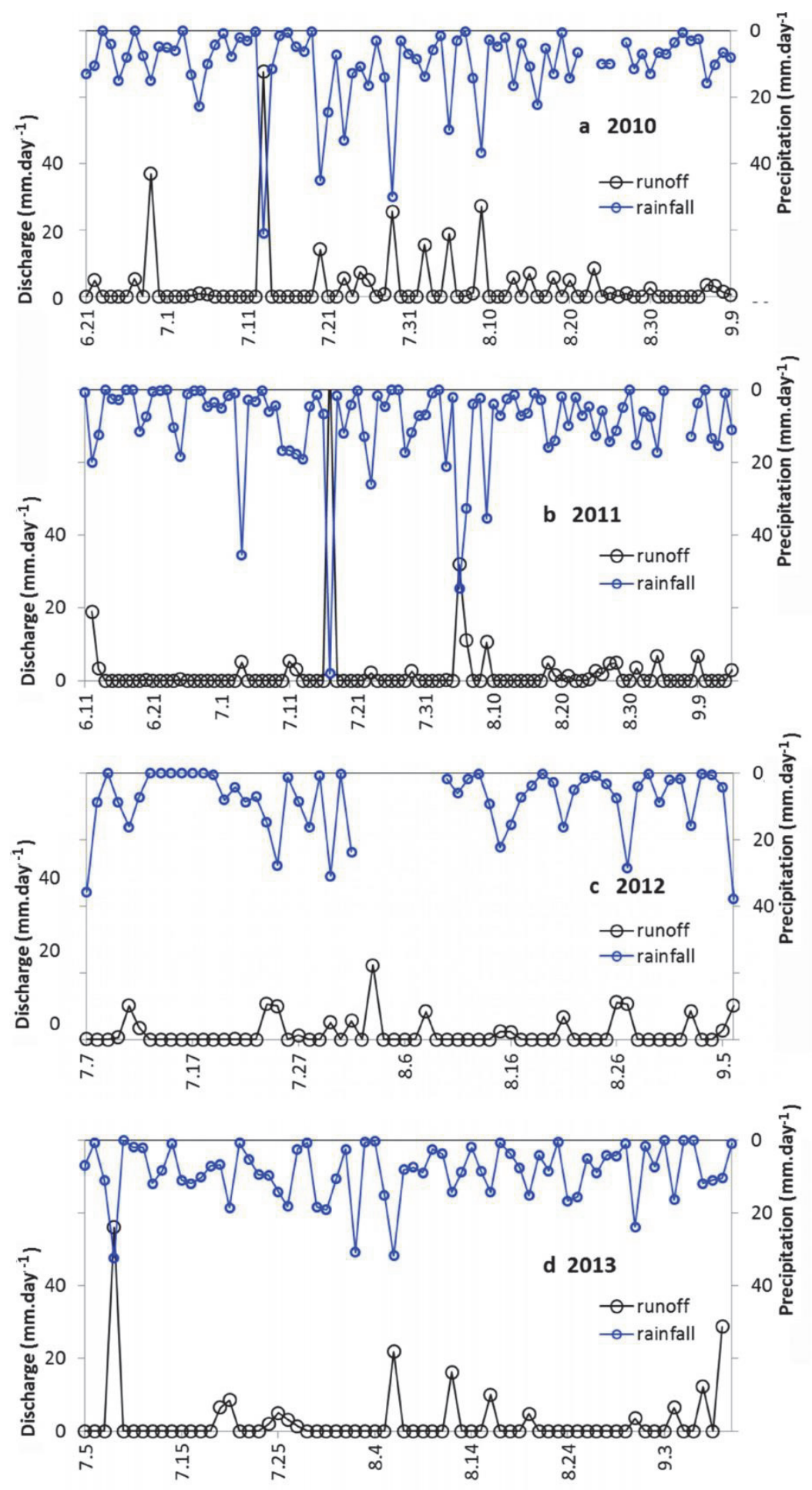

Fig. 6. Precipitation and discharge for the Debre Mawi watershed for the years 2010-2013.

The unconsolidated and disturbed soil from construction of soil bunds together with low vegetation cover may play a role for the elevated sediment concentrations in the beginning of the monsoon. Later in the rainy season (Fig. 8), the sediment concentrations decrease because the rill formation and expansion decline (Tebebu et al., 2010; Tilahun et al., 2013a; Tilahun et al., 2013b; Zegeye et al., 2010) with greater concentrations during high flow events compared to the small storms due to less stream power (Song et al., 2014). Though concentrations decrease due to the vegetation cover, unlike in developed countries, the cover does not provide full canopy because of the low nutrient status of the soils and lower fertilizer application in the Debre Mawi watershed.

A large amount of sediment was trapped in the infiltration furrows of bunds on the hillsides and mid slopes (Fig. 7). The average depth of infiltration ditches when constructed were 50 $\mathrm{cm}$. Our measurement of soil trapped in the infiltration ditches showed that, on the hillsides an average $21 \mathrm{~cm}$ of sediment was 

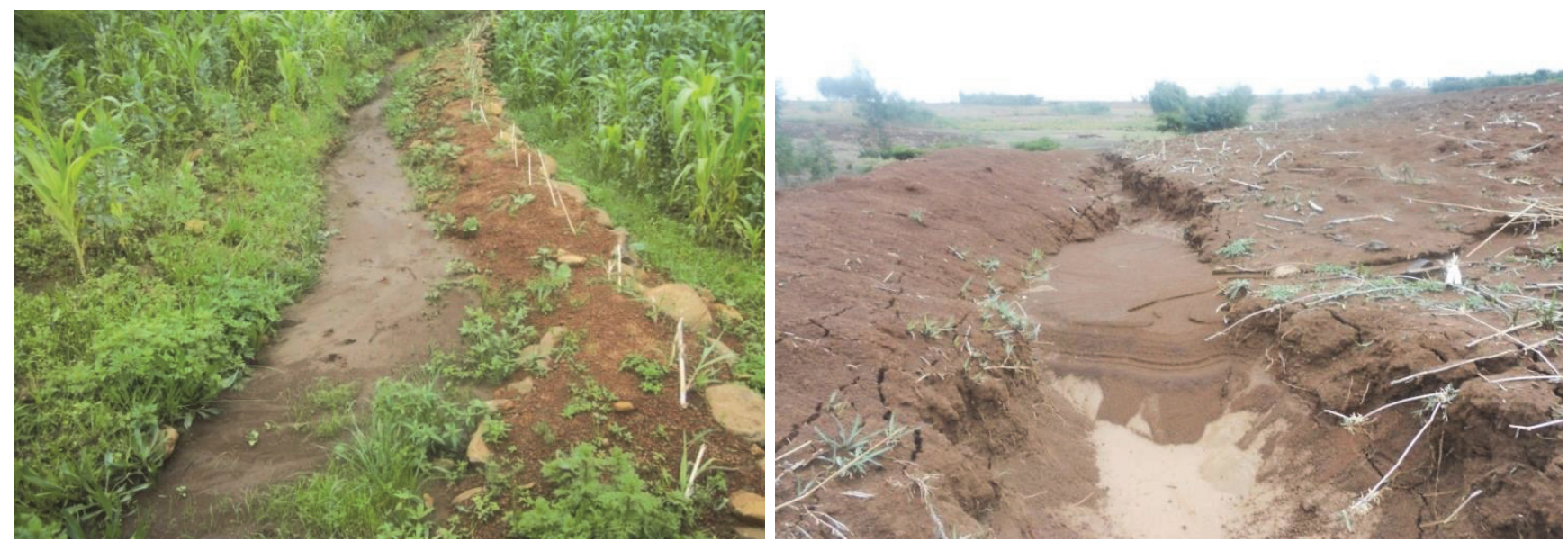

Fig. 7. Large amount of sediment trapped at the furrows of soil bunds at the beginning of the rainy season. Note that though the field is not tilled yet, the rills develop early in the beginning of the rainy season in addition to soil disturbance related to the construction of bunds. Also large amount of water infiltrated.

Table 2. Monthly and annual sediment yield for the Debre Mawi watershed.

\begin{tabular}{lcccc}
\hline & \multicolumn{4}{c}{ Monthly sediment yield $\left(\right.$ ton $\left.\mathrm{ha}^{-1}\right)$} \\
\cline { 2 - 5 } & 2010 & 2011 & 2012 & 2013 \\
\hline June & 17.6 & 11.3 & 0 & 0 \\
July & 37.8 & 30.9 & 4.2 & 11.0 \\
August & 8.6 & 7.5 & 4.3 & 1.9 \\
September & 1.5 & 0.6 & 0.5 & 0.1 \\
Total & 65.5 & 49.8 & 9.0 & 13.0 \\
\hline
\end{tabular}

Table 3. Suspended sediment concentrations for the Debre Mawi watershed from 2010-2013.

\begin{tabular}{lcccc}
\hline & \multicolumn{4}{c}{ Sediment concentration $\left(\mathrm{g} \mathrm{L}^{-1}\right)$} \\
\cline { 2 - 5 } & 2010 & 2011 & 2012 & 2013 \\
\hline Mean & 21.8 & 22.8 & 14.0 & 19.9 \\
Std. deviation & 10.5 & 10.3 & 7.6 & 13.5 \\
Minimum & 0.0 & 0.2 & 0.8 & 0.1 \\
Maximum & 93.4 & 62.6 & 42.1 & 57.8 \\
\hline
\end{tabular}

deposited in the ditches of bunds. It might be surprising considering that the sediment concentrations during most storms before and after installation of the conservation practices are not greatly different. The reason is that in the valley bottoms of the watershed, there are several large active gullies covering up to 0.75 ha, expanding each year due to its head cuts and bank failure with loose cohesive soils (Fig. 4). The overland flow picks up sediment in these gullies (Fig. 4) independently from sediment concentration it had when it entered the gully (Zegeye et al., 2014) that is why the sediment concentration from the gullies is very high. Though the bunds have trapped large amounts of silt from the upland erosion, the reduction in sediment concentration cannot be improved and sustained unless treatment of gullies is undertaken in the watershed.

\section{Water table dynamics}

The general trend of the perched ground water table is understandable; water table rises in July, reaches some kind of steady state level around the beginning of August and then decreases in
September when the amounts of rainfall decline. During days without rain, the ground water table declines. The groundwater table is deep upslope, gets shallower in the mid slope and is close to the surface / at the surface down slope in August (Fig. 9).

The water table is deep in the upslope positions because the contributing area is small and the slope is steep. Thus, a relatively small flux with a large driving force provides for fast drainage. The lower slope position has a large drainage area and a low slope and is the convergent area of the lateral sub surface flow and overland flow. To carry off the imposed flux, the water table will rise until it intersects the surface. This pattern is typical for the semi-humid and humid landscapes in the Ethiopian highlands (Bayabil et al., 2010; Engda et al., 2011). In the semi-arid areas, the water table will rise during the rainy season but will not reach the surface (Nyssen et al., 2010). As we will see in the discussion, water table dynamics are extremely important for the design of infiltration furrows, because when the water table intersects the infiltration furrows, water will flow out of the soil instead of into the soil.

\section{DISCUSSION}

The large scale SWC practices implemented in the Debre Mawi watershed have reduced runoff in July and August due to large amount of rainwater infiltrating in the furrows which in turn improved the baseflow response of the catchment. This is indicated by the total volume of discharge for the month of September before and after the SWC. Though the amount of precipitation in September 2012 and 2013 is slightly lower than the previous years (Fig. 5), the volume of discharge for September 2010 and 2011 was $28,350 \mathrm{~m}^{3}$ and $11,492 \mathrm{~m}^{3}$ whereas for 2012 and 2013 it was $19,498 \mathrm{~m}^{3}$ and $31,210 \mathrm{~m}^{3}$ (shown in Table 1). This is likely related to improved base flow because more rainfall infiltrated in the furrows during July and August after the implementation of soil and water conservation measures. The infiltrated water was stored in the soil profile and flows with deeper flow paths to the outlet and appears as interflow and base flow. In September, when rainfall and surface runoff events are smaller than the previous months, interflow and base flows are significant parts of the total flow. The sediment concentrations at the outlet first declined sharply $(63 \%$ reduction of sediment concentration in 2012, Figure 8). Despite the sediment collected in the infiltration furrows of soil bunds, the 2013 reduction in sediment concentration was not as 



Fig. 8. Runoff and suspended sediment concentration in the Debre Mawi watershed for 2010 to 2013. The closed red spheres are the sediment concentrations and the black line represent the discharge.

large as that of 2012. In the watershed, the sediment concentrations are not showing large reduction because of the unconsolidated soil of the collapsed banks in the gullies. A recent study in a nearby gully by Zegeye et al. (2014) showed that the average sediment concentration from the outlet of the large gully is $83 \mathrm{~g}$ $\mathrm{L}^{-1}$. Since these concentrations are close to the transport limit in the stream, decreasing upland erosion would not necessarily reduce sediment concentrations in the streams. To bring reduction in sediment concentration in the rivers, controlling and treatment of gully erosion need to be addressed as part of the large scale soil and water conservation programs in the subhumid and humid Ethiopian highlands.

Although great reduction of sediment loads were observed for the two years after the implementation of SWC works, sustaining these reductions might not be easy. This is because furrows are already half filled with sediment and therefore will fully use their trap efficiency in another two years, filled up furrows cannot collect runoff and sediment. This would be similar to the graded Fanya Juu bunds (infiltration furrows just off the contour, with soils thrown uphill) installed in the Anjeni watershed in the 1980s which were only effective in reducing sediment concentration over a 4-6 year period (El Kamil, 2014).

Continuous maintenance is needed to keep the infiltration furrows and this could be expensive. Thus, other inexpensive and more sustainable ways to increase infiltration are required. Research in to the effect of planting of deep rooted plants on bunds perhaps together with deep plowing by breaking the hardpan to increase infiltration could be an area of further investigation.

Although in the upper part of the watershed the infiltrations furrows were effective and water could infiltrate because the water table was below the bottom of the furrows (Fig. 9), this 
was not the case in the lower parts of the watershed, where the water table was near the surface and the soils saturate. When the soil is saturated, the water cannot infiltrate in the furrow and the soil strength decreases. The loss of soil strength results in the collapse of soil bunds and sliding into the furrows. In fields where the groundwater is slightly deeper (such as in Fig. 9), the bunds are stable and they carry the drainage water off the field while any excess saturated flow through the furrows will flow at the end of the furrow down the hill and are initiating gullies (Fig. 10). Our findings are similar to that of Mitiku et al. (2006), who noted that improperly designed soil and water conservation structures are the cause of one third of erosion in the highlands of Ethiopia.
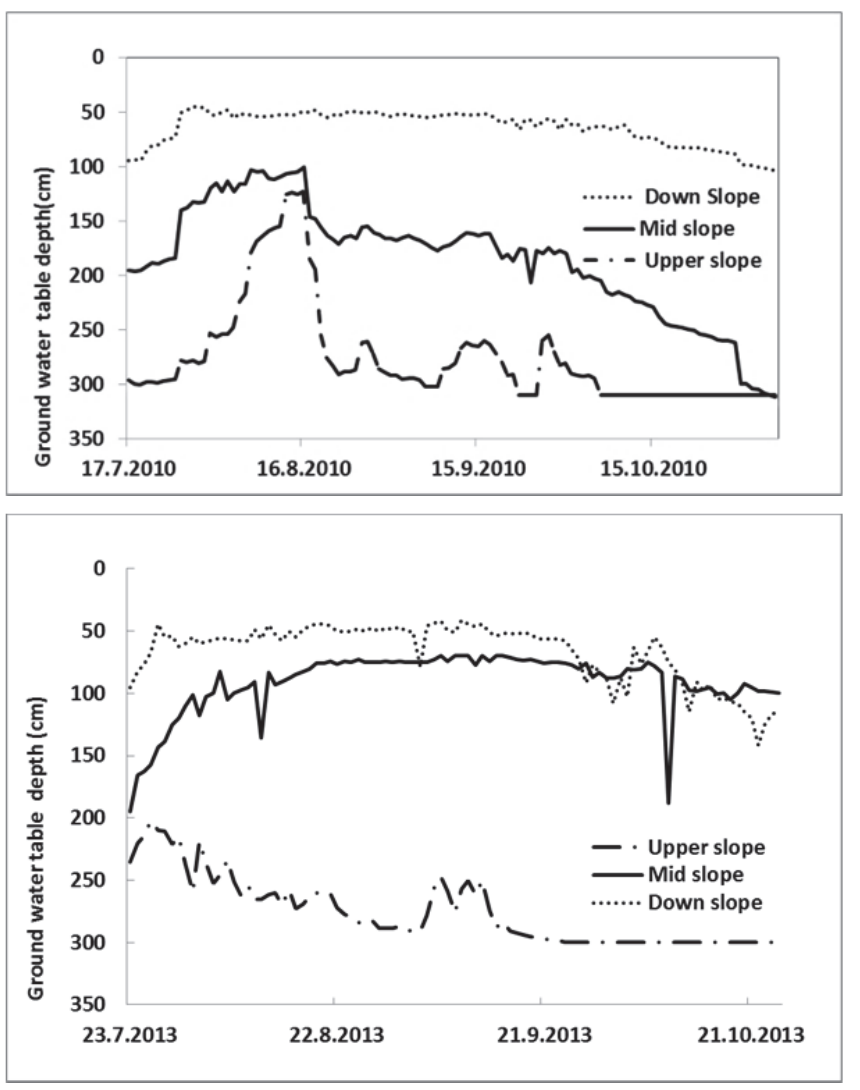

Fig. 9. Average groundwater depth for upslope, midslope and down slope positions in the Debra Mawi watershed for the year 2010 and 2013.

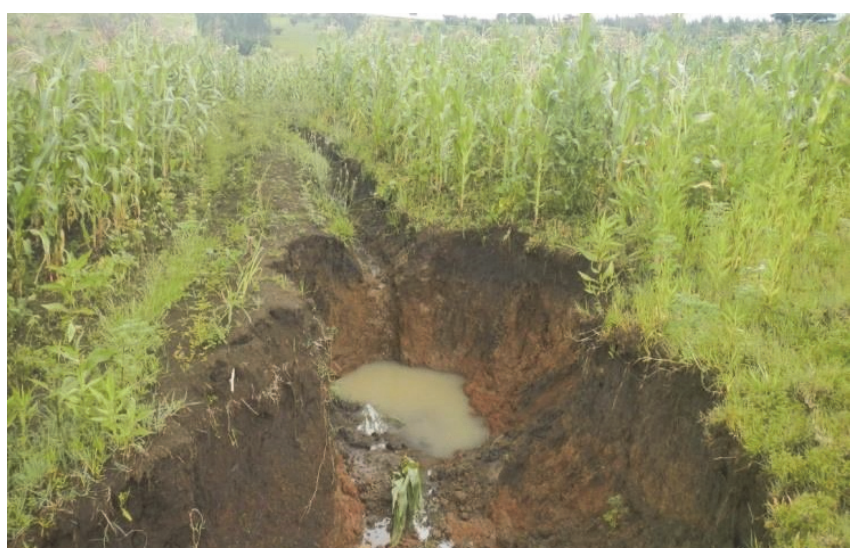

Fig. 10. Gully formed due to failure of soil bunds in the saturated bottom lands (down slope) in Debre Mawi watershed.
In the governmental led implementation large scale watershed management programs in the Debre Mawi watershed, SWC practices are placed uniformly across the landscape without attention to site-specific characteristics such as ground water table dynamics, slope gradients and gully formation. For the government led large scale SWC campaigns to be fully successful in reducing surface runoff and sediment concentration, local conditions of the landscape such as ground water tables and gully treatment and rehabilitation should be taken into account.

\section{CONCLUSIONS}

In this study, we tried to assess the effects of soil and water conservation implementation on runoff and soil loss in a small agricultural watershed called Debre Mawi, Upper Blue Nile Basin. Conservation measures such as soil bunds and stone faced soil bunds with infiltration furrows were gradually installed by farmers through a governmental led national campaign. The soil and water conservation measures resulted in a significant reduction of runoff volume and sediment loads in the first two years of implementation though sediment concentration remained at elevated levels due to the presence of large gullies near the watershed outlet.

Increased performance of governmental soil and water conservation campaigns can be achieved by taking local conditions into account such as high ground water tables that prevent infiltration of rain water and reduce not only the performance of the practices but could be the cause of sediment loss as well. In addition, gully formation should be addressed for reducing sediment concentrations. Finally, maintenance is a must for the long term sustainability of the practices.

Acknowledgements. Funding for this research was obtained from the USAID through the research project called "Participatory Enhanced Engagement in Research" or PEER Science project (grant number AID-OAA-A-11-00012) and from the International Foundation for Science (IFS - grant number W/5565-1). Additional funding was also obtained from Higher Education for Development (HED), United States Department of Agriculture (USDA) and funds provided by Cornell University partly through the highly appreciated gift of an anonymous donor. We also thank the Amhara Region Agricultural Research Institute (ARARI) for providing some of the discharge and sediment data for the outlet weir.

\section{REFERENCES}

Abiy, A.Z., 2009. Geological controls in the formations and expansions of Gullies over hillslope hydrological processes in the highlands of Ethiopia, Northern Blue Nile Region. Cornell University.

Bayabil, H.K., Tilahun, S.A., Collick, A.S., Yitaferu, B., Steenhuis, T.S., 2010. Are runoff processes ecologically or topographically driven in the (sub) humid Ethiopian highlands? The case of the Maybar watershed. Ecohydrology, 3, 457-466.

Bewket, W., Sterk, G., 2002. Farmers' participation in soil and water conservation activities in the Chemoga watershed, Blue Nile basin, Ethiopia. Land Degradation and Development, 13, 189-200.

Bosshart, U., 1995. Catchment Discharge and Suspended Sediment Transport in the Highlands of Ethiopia and Eritrea, $\mathrm{Ph} . \mathrm{D}$. Thesis,University of Berne, Switzerland. 
Constable, M., Belshaw, D., 1986. The Ethiopian highlands reclamation study: major findings and recommendations. ONCCP (Office of the National Committee for Central Planning). Towards a food and nutrition strategy for Ethiopia: Proceedings of the national workshop on food strategies for Ethiopia, pp. 8-12.

Dejene, A., 2003. Integrated natural resources management to enhance food security. The case for community-based approaches in Ethiopia. Environment and Natural Resources. Working Paper (FAO).

El Kamil, M.I., 2014. Trends in river discharge and sediment concentrations in the (semi) humid watersheds of the Blue Nile in Ethiopia. A thesis presented to Cornell University in partial fulfilment of the requirements for the Degree of Master of Professional Studies in Integrated Watershed Management.

Engda, T.A., Bayabil, H.K., Legesse, E.S., Ayana, E.K., Tilahun, S.A., Collick, A.S., Easton, Z.M., Rimmer, A., Awulachew, S.B., Steenhuis, T.S., 2011. Watershed hydrology of the (semi) humid Ethiopian Highlands. Nile River Basin. Springer.

Herweg, K., Ludi, E., 1999. The performance of selected soil and water conservation measures - case studies from Ethiopia and Eritrea. Catena, 36, 99-114.

Hurni, H., 1978. Soil erosion forms in the Simen mountainsEthiopia (with map 1: 25 000). Geographica Bernensia G, 8, 93-100.

Hurni, H., 1983. Soil erosion and soil formation in agricultural ecosystems: Ethiopia and Northern Thailand. Mountain research and development, 131-142.

Hurni, H., 1997. Concepts of sustainable land management. ITC journal, 210-215.

Hurni, H., Tato, K., 1992. Erosion, conservation, and smallscale farming, Geographica Bernensia, c/o Group for Development and Environment.

Laloy, E., Bielders, C.L., 2010. Effect of Intercropping Period Management on Runoff and Erosion in a Maize Cropping System. American Society of Agronomy, Crop Science Society of America, Soil Science Society. doi:10.2134/jeq2009.0239.

McHugh, O.V., Steenhuis, T.S., Abebe, B., Fernandes, E.C.M., 2007. Performance of in situ rainwater conservation tillage techniques on dry spell mitigation and erosion control in the drought-prone North Wello zone of the Ethiopian highlands. Soil \& Tillage Research, 97, 19-36.

Mitiku, H., Herweg, K., Stillhardt, B., 2006. Sustainable land management-A new approach to soil and water conservation in Ethiopia. Mekelle University, Mekelle, Ethiopia, University of Berne, Berne, Switzerland.

MOA, 2013. Annual report of the Ministry of Agriculture for 2013/2014. (unpublished).

MOFED, 2010. Growth and Transformation Plan of Ethiopia (GTP), 2010/2011-2014/15 of the Federal Democratic Republic of Ethiopia (FDRE).

Nyssen, J., Clymans, W., Descheemaeker, K., Poesen, J., Vandecasteele, I., Vanmaercke, M., Zenebe, A., Van Camp, M., Haile, M., Haregeweyn, N., 2010. Impact of soil and water conservation measures on catchment hydrological response - a case in north Ethiopia. Hydrological Processes, 24, 1880-1895.
Sertsu, S., 2000. Degraded soils of Ethiopia and their management. In: Proc. 2nd Network Meeting FAO/ISCW expert consultation on management of degraded soils in Southern and East Africa, Subregional Office for Southern and East Africa; Institute for Soil, Climate and Water, Pretoria Pretoria, pp. 18-22.

Shiferaw, B., Holden, S.T., 1998. Resource degradation and adoption of land conservation technologies in the Ethiopian highlands: a case study in Andit Tid, North Shewa. Agricultural economics, 18, 233-247.

Song, S., Schmalz, B., Fohrer, N., 2014. Simulation and comparison of stream power in-channel and on the floodplain in a German lowland area. Journal of Hydrology and Hydromechanics, 62, 133-144.

Tamene, L., Vlek, P.L., 2008. Soil erosion studies in northern Ethiopia. Land use and soil resources. Springer.

Tato, K., Hurni, H., 1992. Soil conservation for survival, Soil and Water Conservation Society (SWCS).

Tebebu, T.Y., 2009. Assessment of hydrological controls on gully formation near Lake Tana, northern highlands of Ethiopia. Cornell University.

Tebebu, T., Abiy, A., Dahlke, H., Easton, Z., Zegeye, A., Tilahun, S., Collick, A., Kidnau, S., Moges, S., Dadgari, F., 2010. Surface and subsurface flow effect on permanent gully formation and upland erosion near Lake Tana in the northern highlands of Ethiopia. Hydrology and Earth System Sciences Discussions, 7, 5235-5265.

Tilahun, S., Guzman, C., Zegeye, A., Engda, T., Collick, A., Rimmer, A., Steenhuis, T., 2013a. An efficient semidistributed hillslope erosion model for the subhumid Ethiopian Highlands. Hydrology and Earth System Sciences, 17, 1051-1063.

Tilahun, S., Mukundan, R., Demisse, B., Engda, T., Guzman, C., Tarakegn, B., Easton, Z., Collick, A., Zegeye, A., Schneiderman, E., 2013b. A SATURATION EXCESS EROSION MODEL. Transactions of the American Society of Agricultural and Biological Engineers, 56, 681-695. doi: $10.13031 / 2013.42675$.

Tilahun, S.A., 2012. Observations and modeling of erosion from spatially and temporally distributed sources in the (semi) humid Ethiopian highlands. Cornell University.

Walling, D., 1974. Suspended sediment and solute yields from a small catchment prior to urbanization. Fluvial processes in instrumented watersheds, 6, 169-192.

Zegeye, A.D., Steenhuis, T.S., Blake, R.W., Kidnau, S., Collick, A.S., Dadgari, F., 2010. Assessment of soil erosion processes and farmer perception of land conservation in Debre Mewi watershed near Lake Tana, Ethiopia. Ecohydrology and Hydrobiology, 10, 297-306.

Zegeye, A.D., Damtew, S., Langendeon, E., Dagnew, D.C., Tilahun, S.A., Steenhuis, T.S., 2014. Gully development processes in the Ethiopian Highlands. Proceedings of the International Conference on the Advancements of Science and Technology in East Africa (ICAST), Bahir Dar University, Bahir Dar, Ethiopia.

Received 4 July 2014 Accepted 20 February 2015

Note: Colour version of Figures can be found in the web version of this article. 